\title{
Artemis and Her Family
}

Dedicated to the memory of Professor Antonín Bartoněk

(29. 10. 1926 - 30. 5. 2016)

\author{
Václav Blažek \\ (Masaryk University, Brno)
}

\begin{abstract}
The present contribution sumarizes and analyzes the main etymological attempts to explain the theonym 'A $\rho \tau \varepsilon \mu \iota \varsigma$. With regard to vacillation in the root vocalism, the Mycenaean records and the predominance of worship of this goddess in Asia Minor lend precedence to the hypothesis of non-Greek origin. Regarding epithets mediated by ancient authors, it seems that most were transferred from Artemis' brother Apollo. A new solution is based on her epithet Túx " Fortune", known especially from numismatic legends from various cities Peloponnese, Lesbos, and Asia Minor as well as Gerasa in North Jordan. The hypothetical compound *Artemi- would mean "giving omen" in Hurrian, where both components are attested and safely interpreted, and this type of personal name is very frequent. This could have been adopted into Greek in three ways: (i) from a hypothetical language of West Asia Minor related to Hurrian, (ii) from a hypothetical pre-Greek substratum related to Hurrian, or (iii) from Hurrian with Luwoid mediation. It is significant that the names of her brother Apollo and mother Leto are also etymologizable on the basis of Hurro-Urartian languages.
\end{abstract}

\section{Keywords}

theonym; epithet; compound; etymology; Mycenaean; Greek; Hurrian

The Greek theonym Artemis is well attested in both linear B and alphabetic sources, including specific dialect records:

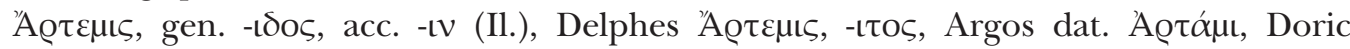

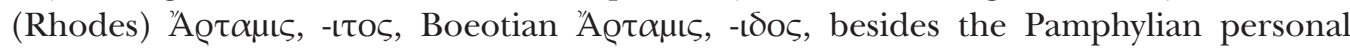

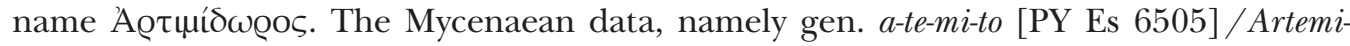
tos/, dat. a-ti-mi-te [PY Un 2195] / Artimitei/ (Aura Jorro 1985: p. 115), confirm the old $t$-stem, but not the vowel $a$ between $t$ and $m$. It should be a result of Volksetymologie in

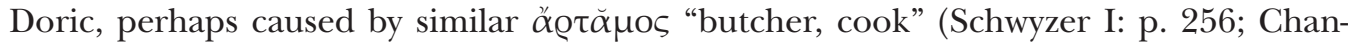
traine I: pp. 116-117). The corresponding theonyms in the Anatolian languages from

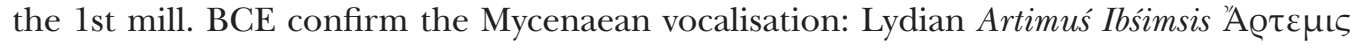




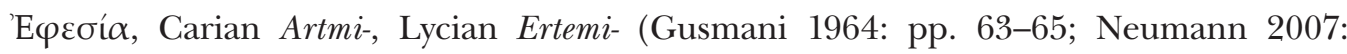
p. 72; Oettinger 2015: p. 137).

The first etymological attempts were formulated already by ancient authors:

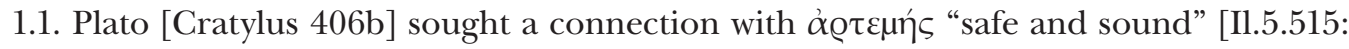

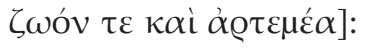

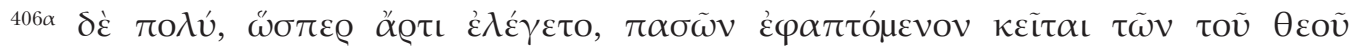

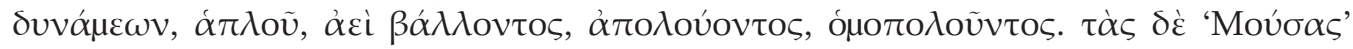

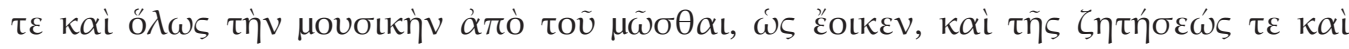

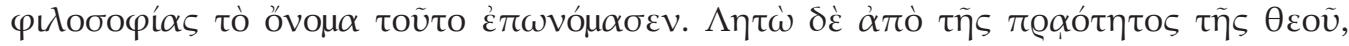

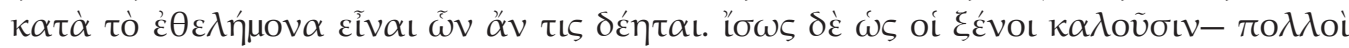

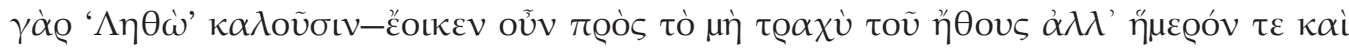
$\lambda \varepsilon \tilde{i} \mathrm{O}$ ' $\Lambda \eta \theta \omega$ '

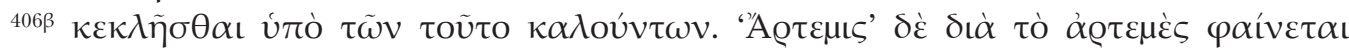

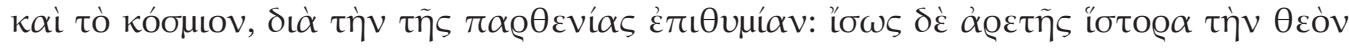

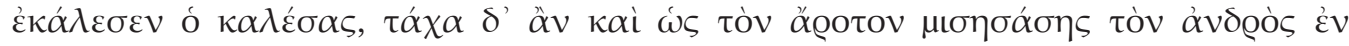

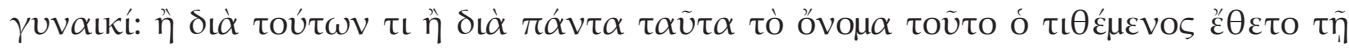
$\theta \varepsilon \tilde{\omega}$.

406a "... Leto \{is named\} from her gentleness, because whatever is asked of her, she is willing. But perhaps her name is Letho, as she is called by many foreigners; and those who call her by that name seem to do so ${ }^{406 b}$ on account of the mild and gentle ( $\lambda \varepsilon \tilde{i}$, $\Lambda \eta \theta \omega)$ kindness of her character. Artemis appears to get her name from her healthy

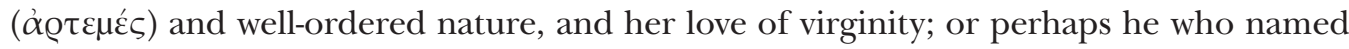

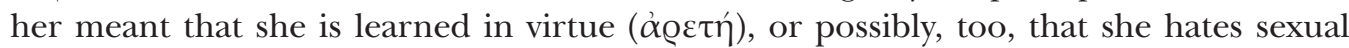

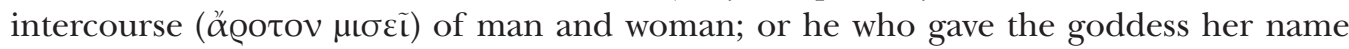
may have given it for any or all of these reasons." (Transl. H. N. Fowler)

It is apparent that Plato offered other solutions as well, but they are already quite bizarre.

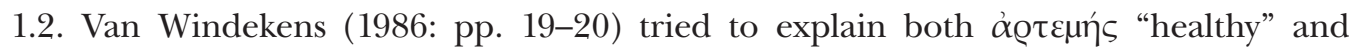

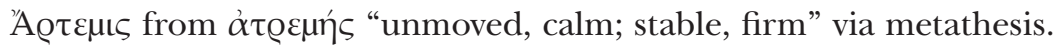

1.3. In recent time Peters (2002: pp. 371f., fn. 60) develops Plato's idea trying to explain

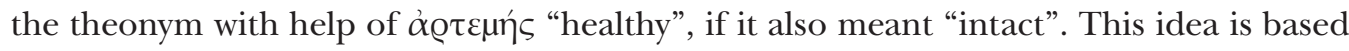

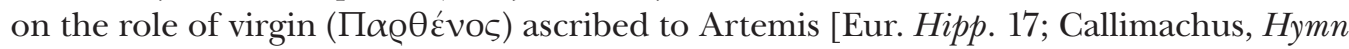

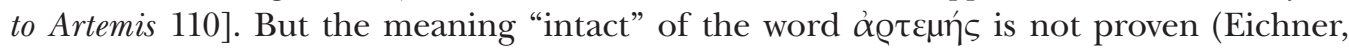
p.c.; cf. Obbink 2014: pp. 37, 40, who identifies this word appearing in a newly discovered papyrus called 'Brothers poem' and translates it traditionally as "safe and sound") and the word itself is obscure (cf. Chantraine I, 117: obscura per obscuriora on etymology based on it). Oettinger (2015: p. 134, fn. 23) judges that the virginity of Artemis was only a later attribute added to her mythological curriculum to complete her role of 'Lady of wild animals'. But with regard to Artemis' role of a healer described in Iliad 5.445-448, 
where Artemis (and her mother Leto) take care of injured Aineias, ${ }^{1}$ the connection be-

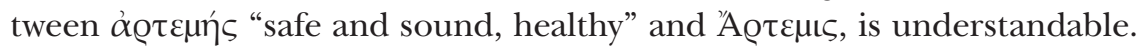

2. Applying another ancient etymology, Liddell \& Scott (1996: p. 248) concluded: Deri-

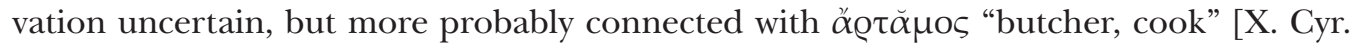
2.2.4; Epicr. 6; IG 14.643], metaphorically "murderer" [S. Fr.1025; Lyc. 236, 797], than

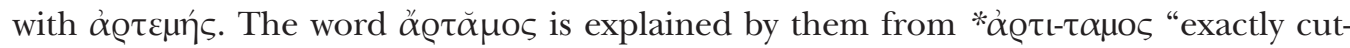
ting", with respect to Eustathius, who in his comments to Iliad from the 12th cent.

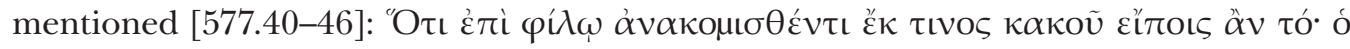

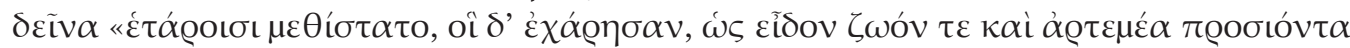

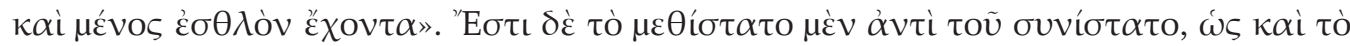

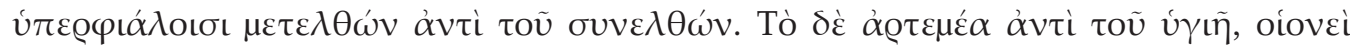

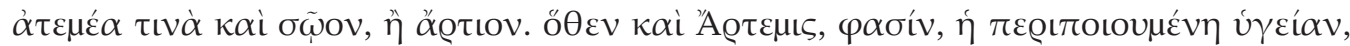

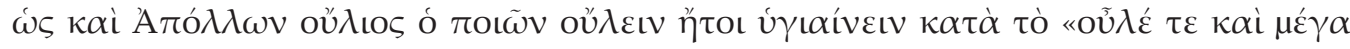

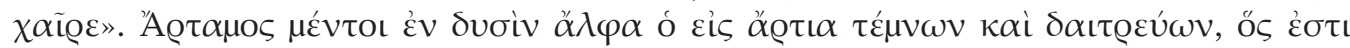

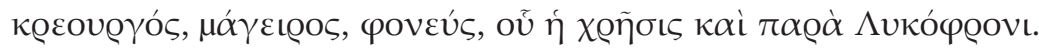

But the semantic side of this etymological attempt is weak. According to her mythological curriculum Artemis had nothing in common with "butcher", nor with "cook". She is described as a "first-class archer", but not "murderer". 2

3. Artemis' skill in archery seems to be derived from her brother. Let us compare the epithets or attributes of Artemis and Apollo connected with archery:

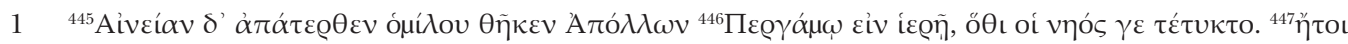

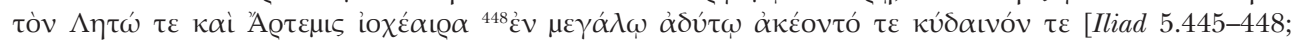
retrieved 18. 10. 2016 from http://data.perseus.org/citations/urn:cts:greekLit:tlg0012.tlg001.perseus-grc1:5.416-5.459].

"Aeneas then did Apollo set apart from the throng in sacred Pergamus where was his temple builded. There Leto and the archer Artemis healed him in the great sanctuary, and glorified him." [Transl. A. T. Murray; retrieved 18. 10. 2016 from http://data.perseus.org/citations/urn:cts:greekLit:tlg0012.tlg001. perseus-eng1:5.416-5.459].

2 Apollo with his sister Artemis are described as protectors of honour of their mother Leto in the passage of Iliad, where these twins are slaying by their arrows six sons and six daughters of Niobe respectively,

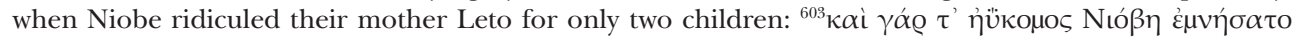

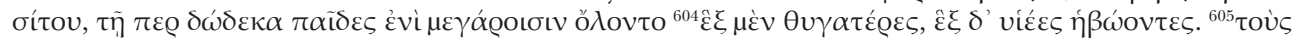

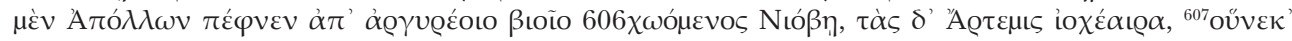

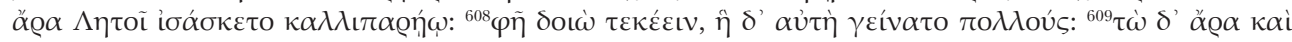

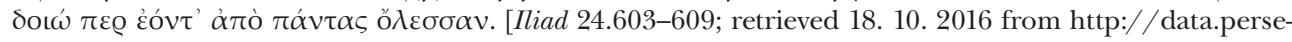
us.org/citations/urn:cts:greekLit:tlg0012.tlg001.perseus-grc1:24.596-24.642].

"For even the fair-haired Niobe bethought her of meat, albeit twelve children perished in her halls, six daughters and six lusty sons. The sons Apollo slew with shafts from his silver bow, being wroth against Niobe, and the daughters the archer Artemis, for that Niobe had matched her with fair-cheeked Leto, saying that the goddess had borne but twain, while herself was mother to many; wherefore they, for all they were but twain, destroyed them all." [Transl. A. T. Murray; retrieved 18. 10. from http://data.perseus.org/citations/urn:cts:greekLit:tlg0012.tlg001.perseus-eng1:24.596-24.642]. 
Table 1. Epithets of Artemis connected with archery

\begin{tabular}{|c|c|c|}
\hline epithet / attribut & literal meaning & source \\
\hline 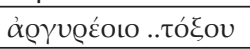 & "of silver bow" & Callimachus, Hymn to Artemis 119 \\
\hline$\dot{\varepsilon} \kappa \alpha ́ \tau \eta \eta$ & "far-shooting" & Aeschyllus, Supplices 676 \\
\hline 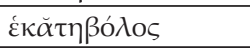 & "far-shooting" & Homeric hymn to Artemis 6 \\
\hline 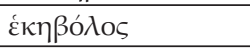 & "far-shooting" & Sophocles, Fragmenta 401 \\
\hline 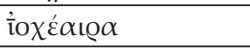 & "with arrows in the hand" & Iliad 5.53, 24.606; as subst. Iliad 21.480; Odyssey 11.198 \\
\hline$\tau \hat{\tau} \xi \alpha$ & "archery" & Callimachus, Hymn to Artemis 2 \\
\hline 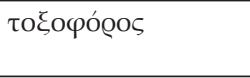 & "bow-bearing" & $\begin{array}{l}\text { Iliad 21.483, Aristophanes, Thesmophoriazusae 970; IG } \\
7.53\end{array}$ \\
\hline
\end{tabular}

Table 2. Epithets of Apollo connected with archery

\begin{tabular}{|c|c|c|}
\hline epithet / attribut & meaning & source \\
\hline$\dot{\alpha} \varepsilon \dot{\iota} \beta \mathrm{o} \lambda \tilde{\omega} \nu$ & "always striking" & Plato, Cratylus 405 \\
\hline 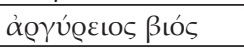 & "silver bow" & Iliad 1.49 \\
\hline 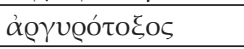 & "that with a silver bow" & Iliad 1.37 \\
\hline$\dot{\alpha} \varphi \eta \dot{\tau} \tau \omega \varrho$ & "archer" & Iliad 9.404 \\
\hline$\dot{\varepsilon \kappa a ́ \varepsilon \varrho \gamma о \varsigma ~}$ & $\begin{array}{l}\text { "far-working" = } \\
\text { "-shooting" }\end{array}$ & Iliad 1.479 \\
\hline 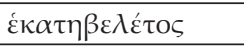 & "far-shooting" & Iliad 1.75; Hesiod, Shield of Heracles 100 \\
\hline 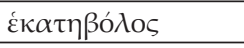 & "far-shooting" & Iliad 15.231 \\
\hline 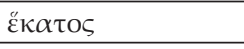 & "far-shooting" & Iliad 20.71 \\
\hline$\dot{\varepsilon \kappa \eta \beta o ́ \lambda o s ~}$ & "far-shooting" & Iliad 23.872; Hesiod, Theogonia 94 \\
\hline 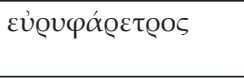 & $\begin{array}{l}\text { "that with a broad } \\
\text { quiver" }\end{array}$ & Pindarus, Fragmenta 115 \\
\hline ì $\pi \tau \varepsilon \oint o ́ \varepsilon v \tau \alpha$ & "winged arrows" & Iliad 20.68 \\
\hline$\kappa \alpha \lambda \lambda \operatorname{cí}_{\mathrm{\tau}} \xi \mathrm{\xi}_{\mathrm{o}}$ & $\begin{array}{l}\text { "that with a beautiful } \\
\text { bow" }\end{array}$ & Aristides, Ars rhetorica 56.1.14 \\
\hline 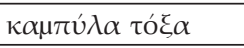 & "curved bow" & Homeric hymn to Apollo 131 \\
\hline 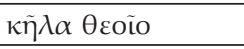 & "divine arrows" & lliad 1.53 \\
\hline 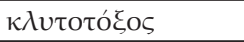 & "famous for the bow" & Iliad 4.101 \\
\hline 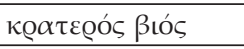 & "strong bow" & Homeric hymn to Apollo 301 \\
\hline 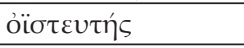 & "archer" & Callimachus, Hymn to Apollo 42 \\
\hline 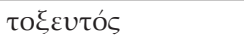 & "struck by an arrow" & Sophocles, Philoctetes 335 \\
\hline 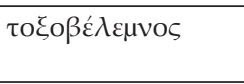 & $\begin{array}{l}\text { "arrow-shooting from } \\
\text { his bow" }\end{array}$ & Orphica Hymni 34, 6 \\
\hline 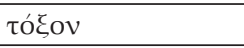 & "archery" & Callimachus, Hymn to Apollo 42-46 \\
\hline 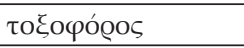 & "bow-bearing" = "archer" & Pindarus, Olympian Odes 6.59 \\
\hline 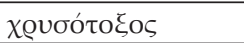 & "that with a golden bow" & Pindarus, Olympian Odes 14.10 \\
\hline
\end{tabular}

Although these lists are not exhaustive, they are representative. From the quantitative point of view the share $7: 22$ between Artemis and Apollo need not mean anything, but 6 of 7 epithets devoted to Artemis are identical with the epithets characterizing Apollo

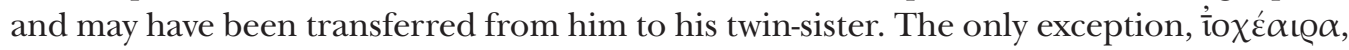
if derived from *ihuo- $k^{h}$ eharia $<* i s u o-k^{h} e s r i a<*(H) i s u o-\hat{g}^{h} e s r-i H_{2}$, meant "with arrow in the 
hands" and corresponds to Vedic ișu-hasta- [RV 10.103.2] (Pisani 1947: p. 142; Heubeck 1956: pp. 275-279; Beekes 1969: p. 279). Traditionally the second member of the compound has been explained from the verb $\chi \dot{\varepsilon} \omega$ "I pour", leading to the rather strange meaning "arrow-pourer" (cf. Benveniste 1935: p. 27). All details of both etymologies are discussed by Peters (1980: pp. 223-228).

4. Similar conclusions may be formulated in the case of other characteristics:

4.1. "hunter"

\begin{tabular}{|c|c|}
\hline Apollo & Artemis \\
\hline 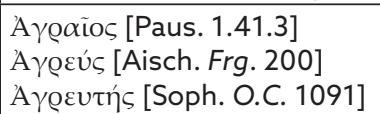 & 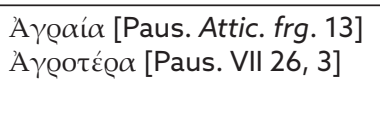 \\
\hline
\end{tabular}

4.2. "road-guardian"

\begin{tabular}{|c|c|}
\hline Apollo & Artemis \\
\hline A $\gamma v i \varepsilon v ́ s$ [Eur. Phoen. 631] & 'Evodí $\alpha$ [Hesych.] \\
\hline
\end{tabular}

\section{3. "light"}

\begin{tabular}{|c|c|}
\hline Apollo & Artemis \\
\hline 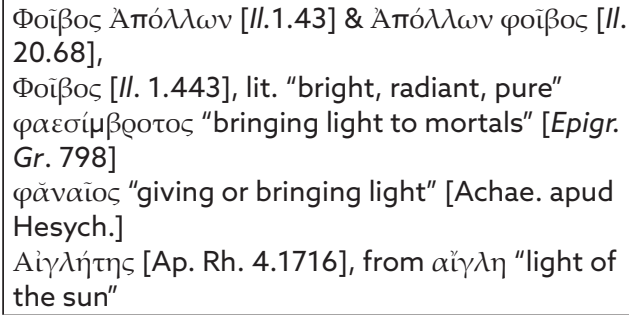 & 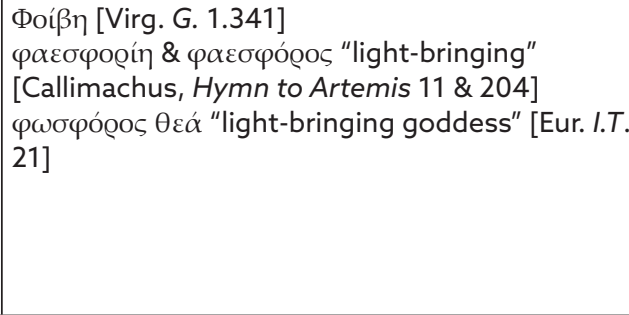 \\
\hline
\end{tabular}

\section{4. "healing"}

\begin{tabular}{|c|c|}
\hline Apollo & Artemis \\
\hline 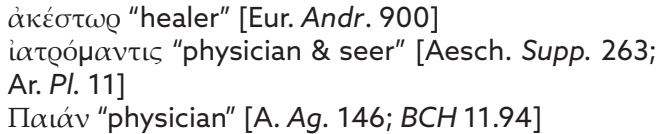 & 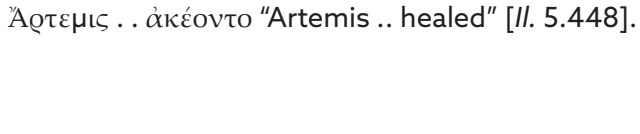 \\
\hline
\end{tabular}

\section{5. "prophecy"}

\begin{tabular}{|c|c|}
\hline Apollo & Artemis \\
\hline 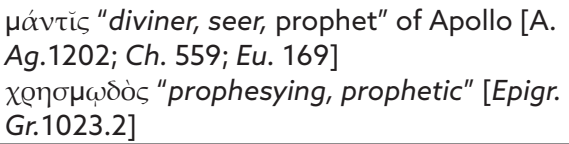 & $\begin{array}{l}\text { Túxך "fortune, providence, fate" [Orphic hymn } 72 \\
\text { to Tyche }{ }^{3} \text {. }\end{array}$ \\
\hline
\end{tabular}

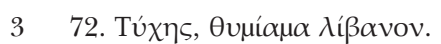

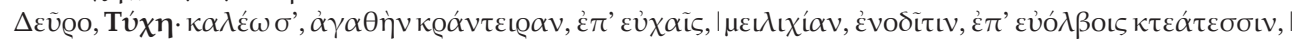

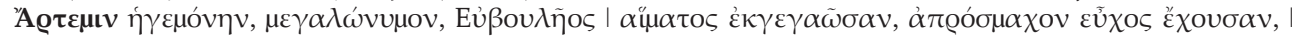

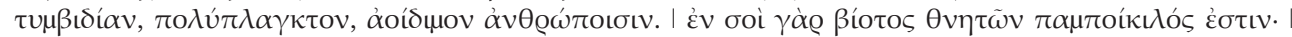

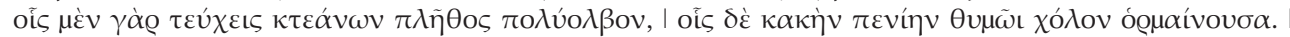

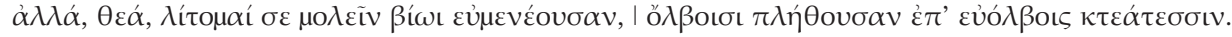


The identification of Artemis with Tyche appears e.g. in the legend from the red jasper

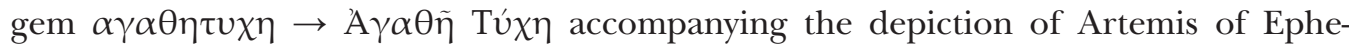

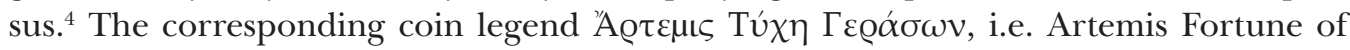
Gerasa, is known from the North Jordan city Gerasa, today Jerash (Lichtenberg 2008: pp. 142-144). Similar identifications occur in coin legends unearthed in some other cities, namely in Ephesus (Ionia); Acrasus (Lydia); Perge (Pamphylia); Mytilene (Lesbos),

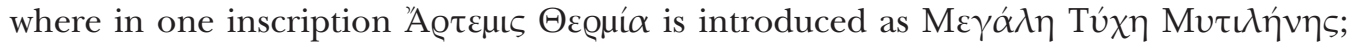
Amyclae (Laconia); Messene (southwest Peloponnese) [Pausanias 4.31.10 mentioned the statues of Tyche and Artemis were situated besides themselves in Messene ${ }^{5}$ ] (see Wernicke 1895b: c. 1369). The oracles of Artemis were situated e.g. on the island Delos, one of the Cyclades archipelago, where the birthplace of the twins Artemis and Apollo was situated; further Didymaion near Miletus; Adrasteia in Propontis [Strabo XIII 587]; Pylai in Kilikia, where the oracle of Artemis Sarpedonia was located [Strabo XIV 5.19]; Seleukeia in Pamphylia [Strabo XIV 676]; at a later time also in the temple of Artemis Pergaia in Perge in Pamphylia [Strabo XIV 4. 2; cf. Callimachus, Hymn to Artemis 187] etc. (Wernicke 1895b: c. 1353; http://www.theoi.com/Cult/ArtemisCult4.html). There

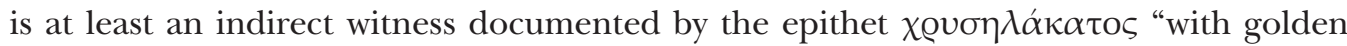
spindle" [Il. 20.70; Soph. Tr. 637], that Artemis had something in common with Moĩo $\alpha$, spinning fates of all mortals. Another witness to this connection was mediated by Callimachus in his Hymn to Artemis, ${ }^{6}$ vv. 20-23.

72. Tyche (or Fortune) The Fumigation from Frankincense.

"Approach strong Fortune, with propitious mind I And rich abundance, to my prayer inclined: ।

Placid, and gentle Trivia, mighty named, I Imperial Dian, born of Pluto famed; |

Mankind's unconquered, endless praise is thine, I Sepulcheral, widely-wandering power divine! |

In thee, our various mortal life is found, I And some from thee in copious wealth abound;

While others mourn thy hand averse to bless, I In all the bitterness of deep distress.

Be present, Goddess, to thy votery kind, I And give abundance with benignant mind." [Transl. T. Taylor; retrieved 18. 10. 2016 from https://drive.google.com/file/d/0B5oS3sKmDYfwT0FpWkxVVXdhVlU/ view].

4 Amulet(?) gem: Artemis of Ephesus. In The Campbell Bonner Magical Gems Database. Retrieved 18. 10. 2016 from http://www2.szepmuveszeti.hu/talismans/cbd/2245.

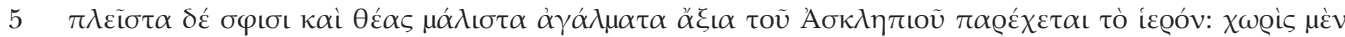

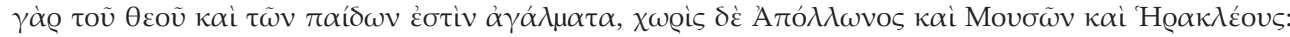

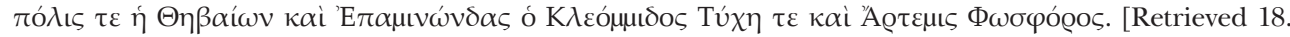
10. 2016 from http://data.perseus.org/citations/urn:cts:greekLit:tlg0525.tlg001.perseus-grc1:4.31.10].

"The most numerous statues and the most worth seeing are to be found in the sanctuary of Asclepius. For besides statues of the god and his sons, and besides statues of Apollo, the Muses and Heracles, the city of Thebes is represented and Epaminondas the son of Cleommis, Fortune, and Artemis Bringer of Light." [Transl. W. H. S. Jones \& H. A. Ormerod; retrieved 18. 10. 2016 from http://data.perseus.org/citations/ urn:cts:greekLit:tlg0525.tlg001.perseus-eng1:4.31.10].

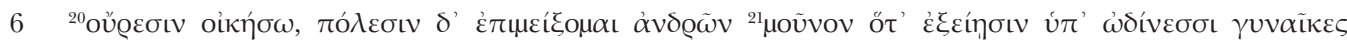

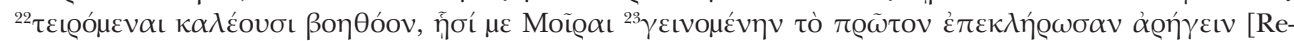
trieved 18. 10. 2016 from http://data.perseus.org/texts/urn:cts:greekLit:tlg0533.tlg017.perseus-grc1].

"On the mountains will I dwell and the cities of men I will visit only when women vexed by the sharp pang of childbirth call me to their aid even in the hour when I was born the Fates ordained that I should be their helper..." [Transl. A. W. Mair; retrieved 18. 10. 2016 from http://www.theoi.com/Text/CallimachusHymns1.html\#3]. 
5. The present six characteristics, archery, hunting, road-guardian, light, healing, prophecy, are more or less common to the twins Apollo and Artemis. They do not cover their mythological curricula exhaustively, but significantly. If some of them agreed with functional semantics of their names determined via etymological analysis, such a solution would be more probable than others. If the theonyms Artemis and Apollo are not etymologizable in Greek, it is necessary to seek their etymologies in other languages used in the Eastern Mediterranean in the 2nd mill. BCE, which could represent a cultural impact on the Mycenaean world.

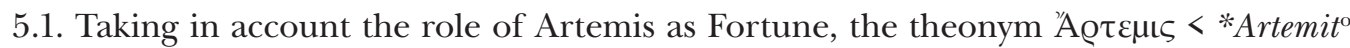
may be analyzed with help of Hurrian, the language with a cuneiform epigraphic tradition from the 2nd mill. BC. The Hurrian cuneiform inscriptions were unearthed in Eastern Anatolia, Northern Mesopotamia and Syria. Some of Cypro-Minoan inscriptions from Cyprus (e.g. from Enkomi) may also be written in Hurrian. The theonym is explainable as a compound of the Hurrian verb ar- "to give" and the noun $\operatorname{tem}(\mathrm{m}) i$ "signe omineux" (Laroche 1980: pp. 52, 262), together perhaps "giving omen”. The root $a r$-forms frequently the first member of Hurrian personal names (cf. Nozadze 2007: pp. 79-85):

Ar-kanta, Ar-kapi E Ar-kapinni, Ar-nanta, Ar-naphi, Ar-nawar, Ar-nupar, Ar-nupatal, Arnuzu : URUNuzue 'city Nuzi', Ar-papa : paba "mountain", Ar-puruša, Ar-siluni, Ar-šahalu, Ar-šali, Ar-šalipe, Ar-šanta E̋ Ar-šatna, Ar-šarri : šarri "king" < Akkadian, Ar-šatuya, Ar-šawa, Ar-šawuška : 'Šawuška 'goddess', derived from šau- "weapon”, Ar-šehala \& Ar-šshli : šehal"pure, clean”, Ar-šelli, Ar-šenni : šeni "brother", Ar-šikiya, Ar-šimika : "Šimigi "sun(-god)", Ar-šuliḩe, Ar-tae, Ar-tahuma, Ar-tahupi, Ar-tamuzi, Ar-tarpašh̆e, Ar-tašenni : tašenni "present", Ar-tatal, Ar-tatappi, Ar-teya, Ar-temtue : temmi "omen”, Ar-tešše, Ar-tešup : Tešub "storm-god", Ar-timaluk, Ar-timuri, Ar-tiranna, Ar-tirwi, Ar-titi, Ar-tuki, Ar-tunni, Ar-tura, Ar-durubla, Arwatiya, Ar-zarwa, Ar-zikari, Ar-ziluk, Ar-zizza.

The Hurrian compound Ar-tem $(m) i$ - would mean "giving omen". The fact that the

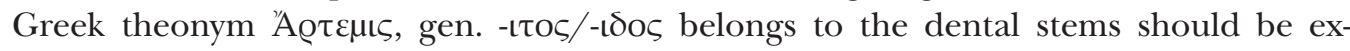
plained already from the donor-language. It seems, it could be explained with the derivational suffix $-t / d i$ - formed abstract nouns in Hurrian, e.g. $k e l=d i$ "health" vs. kel- "to be healthy", or eman=di "Zehnerschaft" vs. eman- "ten" (Wegner 2007: p. 59). There is perhaps a parallel anthroponym Ar-temtue, where -tu- is a formative occuring in proper names and $-e$ is the thematic vowel of nouns, identified e.g. in tahe "man", arde "city", ěse "earth", tive "word" (Nozadze 2007: pp. 109, 382-383; Wegner 2007: p. 52).

5.2. Taking in account the dominant characteristics of Apollo as an archer (see §3), a promising key to the etymology of the theonym A $A$ ó $\lambda \lambda \omega v$, with regard to Cypriotic A A $\pi$ í $\lambda \omega v$,

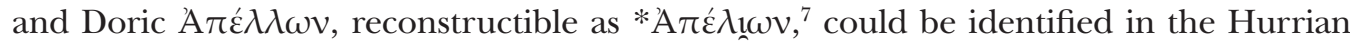

7 In Mycenaean the theonym is not securely attested, only the incomplete form ]pe-rjo[ known from Knossus [KN E 842.3], may reflect the dat. [a]-pe-rjo-[ne], leading to the starting-point *A A $\varepsilon \lambda \_\omega v$ (cf. Ruijgh 1967: p. 274; Heubeck 1987: p. 180; Aura Jorro 1993: p. 113; Beekes 2010: p. 118). But there is also an alternative interpretation [u]-pe-rjo-ne of Ventris \& Chadwick (1973: p. 571), leading to the divine name ' $\Upsilon \pi \varepsilon \rho i ́ \omega v$ [Il. 19.398 etc.]. 
(see CDA 20) word for "arrow", borrowed into Akkadian of Nuzi as apellu "kind of arrow" (AHw. 57) or "arrowhead" (CAD I, 169). Let us mention that the final $-u$ is the Akkadian nominative. The original Hurrian form might probably have been ended in $-i$, if it was a derivative of a verbal root, cf. Hurrian fur-i "view" vs. fur- "to see", han-i "child" vs. han"to give birth", mad-i "wisdom" vs. mad- "to be wise" (Wilhelm 2004: p. 102). Concerning the word-formation of a hypothetical source of the Greek theonym, it is possible to think about a parallel structure as in Hurrian $m \bar{a} d(i)=O=n n i$ "wise" vs. madi "wisdom", $p i c=0=n n i$ "joyful” vs. pico "joy" (Wilhelm 2004: p. 106; Wegner 2007: p. 55). In this case the original Hurrian archetype could be reconstructed as *apell $(i)=0=n n i \pm$ "characterized by arrows". In the process of adaptation into Greek the final $-i$ could have been reinterpreted as the

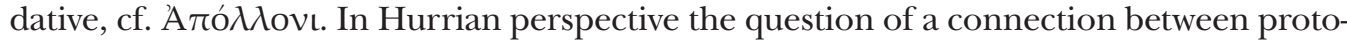
Greek *Apelíón, the protector of (W)ilios, and ${ }^{\mathrm{d}} A$ Ap-pa-li-u-na-aš, one of the deities of Wiluša mentioned in Hittite annals [KUB XXI 1 iv 27] (cf. García Trabazo 2007: pp. 52-53), may be interpreted in a way other than a Hittite adaptation of the Greek theonym - both theonyms could represent independent adaptations of a primary Hurrian theonym or an epithet of some Hurrian deity (details are discussed in Blažek 2015).

5.3. If the theonyms Artemis and Apollo are of Hurrian origin or represent adaptations from a language related to Hurrian, one would expect a similar origin for the name of

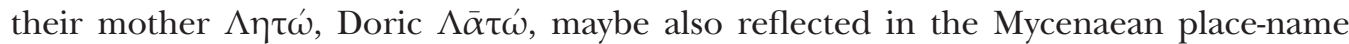
ra-to [KN D-2 ${ }^{2}$ (Aura Jorro 1993: 226-227; Beekes 2010: 858-859). Her characteristics are summarized by Hesiod in his Theogony: "mild", "kind" and "gentle", and further "dark-gowned". None of these attributes offer any solution to explaining her name. ${ }^{9}$ It seems, though, that a key may be found in her role of "wife" of Zeus (probably preced-

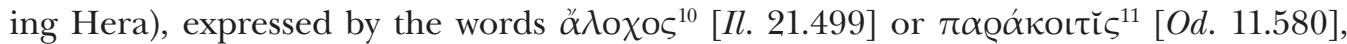

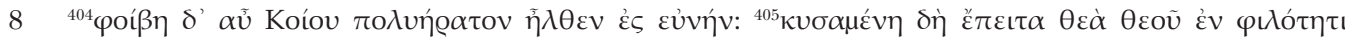

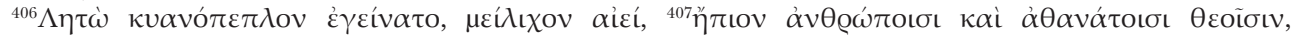

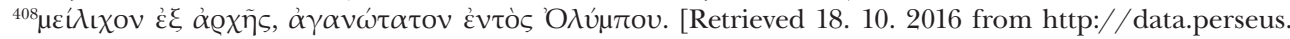
org/citations/urn:cts:greekLit:tlg0020.tlg001.perseus-grc1:404-452].

"Again, Phoebe came to the desired embrace of Coeus. Then the goddess through the love of the god conceived and brought forth dark-gowned Leto, always mild, kind to men and to the deathless gods, mild from the beginning, gentlest in all Olympus." (Transl. H. G. Evelyn-White; retrieved 18. 10. 2016 from http://data.perseus.org/citations/urn:cts:greekLit:tlg0020.tlg001.perseus-eng1:404-452].

9 Peters (2002: p. 371, fn. 40) seeks origin of the theonym in the noun *lá $\mathrm{H}_{2}$-to- "Verborgenheit" (cf. Pokorny 1959: p. 651; LIV 401). Alternatively he thinks about a connection to $\lambda \eta \mu \eta \eta$ "humour in the corner of the eye". Besides semantic problems of his solutions, Oettinger (2015: p. 134, fn. 22) mentions the to-formations usually extend the zero-grade of the root.

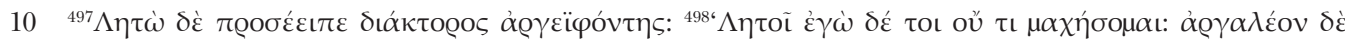

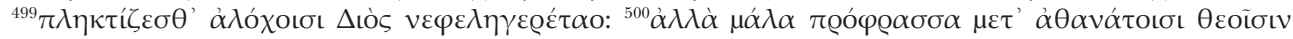

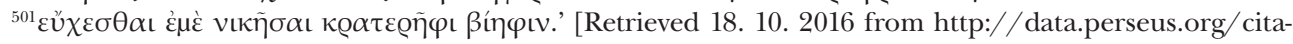
tions/urn:cts:greekLit:tlg0012.tlg001.perseus-grc1:21.468-21.501].

"But unto Leto spake the messenger Argeiphontes: 'Leto, it is not I that will anywise fight with thee; a hard thing were it to bandy blows with the wives of Zeus, the cloud-gatherer; nay, with a right ready heart boast thou among the immortal gods that thou didst vanquish me with thy great might'." [Transl. A. T. Murray; retrieved 18. 10. 2016 from http://data.perseus.org/citations/urn:cts:greekLit:tlg0012.tlg001. perseus-eng1:21.468-21.501.] 
besides $\lambda \varepsilon \chi \omega^{12}$ "woman in child-bed" [Call. Del. 56]. In this perspective a hypothetical source of the theonym *Läto may be related to the predecessor of Urartian lutu "woman" (probably with the plural suffix $-t u$, which could cause the change $* l a d+t u>l u t u$ ). Urartian lutu "woman" is probably related to Daghestanian counterparts such as Avar $\lambda \lambda a ́ d i$ "wife", pl. $\lambda \lambda u d-b i$, Agul xir, Chiragh xade "woman" etc. (Diakonoff \& Starostin 1986: p. 27; NCED 764-765; Hüsing 1918: pp. 267-271; he added Lycian lada "uxor” see discussion by Neumann 2007: pp. 180-183). It should not be surprising that the most probable etymology of the name of the usual first lady of the supreme god Zeus, namely "Hō , Cypriotic dat. e-ra-i, Mycenaean dat. e-ra [PY+TH]/Hèrāi/, leads to the startingpoint *sērā "lady/woman", cf. Latin Iūnō Sorōria, Avestan häiriš̄̌ "female" (Willi 2010).

\section{Conclusion}

Summing up, all members of the theonymic triad *Artemit ${ }^{\circ}$, Apelion, and ${ }^{*}$ Lātō, are etymologizable on the basis of Hurro-Urartian languages. Three ways of borrowing are possible: (i) From a hypothetical language of West Asia Minor related to Hurrian. (ii) From a hypothetical pre-Greek substratum related to Hurrian. (iii) From Hurrian with mediation of some Luwoid language preserving the vowel $e$, which was eliminated from both the epigraphic variets, Cuneiform and Hieroglyphic Luwian.

Abbreviations: KN Knossus; KUB Keilschrifturkunden aus Boghazköi; PY Pylus; RV Rgveda; TH Thebae.

Note: The abbreviations of the Greek authors and their texts follow Liddell \& Scott (1996).

\section{Bibliography}

Abel, E. (Ed.). (1885). Orphica. Recensuit Eugenius Abel. Accedunt Procli Hymni, Hymni Magici, Hymnus in Isim alique eiusmodi carmina. Leipzig: Freytag - Prag: Tempsky. [Retrieved 18. 102016 from https://archive.org/details/orphicarecensuit00orph].

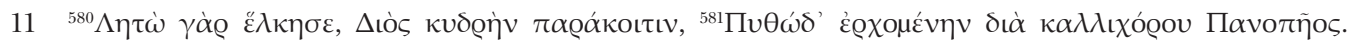
[Retrieved 18. 10. 2016 from http://data.perseus.org/citations/urn:cts:greekLit:tlg0012.tlg002.perseus-grc1:11.567-11.600].

"For he had offered violence to Leto, the glorious wife of Zeus, as she went toward Pytho through Panopeus with its lovely lawns." [Transl. A. T. Murray; retrieved 18. 10. 2016 from http://data.perseus.org/ citations/urn:cts:greekLit:tlg0012.tlg002.perseus-eng1:11.567-11.600].

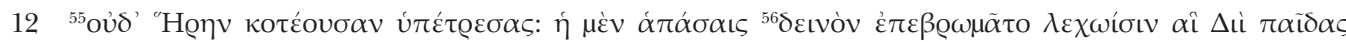

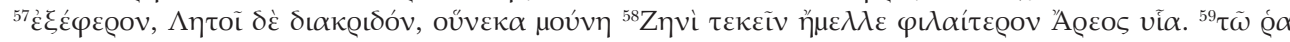

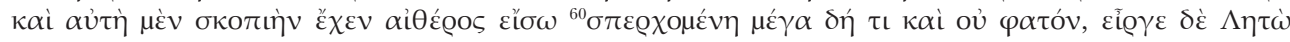

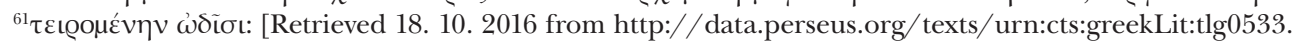
tlg018.perseus-grc1].

"And thou didst not tremble before the anger of Hera, who murmured terribly against all child-bearing women that bare children to Zeus, but especially against Leto, for that she only was to bear to Zeus a son dearer even than Ares. Wherefore also she herself kept watch within the sky, angered in her heart greatly and beyond telling, and she prevented Leto who was holden in the pangs of childbirth." [Transl. A. W. Mair; retrieved 18. 10. 2016 from http://www.theoi.com/Text/CallimachusHymns2.html]. 
AHw. = Soden, W. von (1965). Akkadisches Handwörterbuch (Vol. I). Wiesbaden: Harrassowitz.

Aura Jorro, F. (1985-1993). Diccionario micénico (Vol. I-II). Madrid: Instituto de Filología / Consejo superior de investigaciones científicas.

Beekes, R. (1969). The Development of the Proto-Indo-European Laryngeals in Greek. The Hague-Paris: Mouton.

Beekes, R. (2003). The Origin of Apollo. Journal of Ancient Near Eastern Religions, 3(1), 1-21.

Beekes, R., \& van Beek, L. (2010). Etymological Dictionary of Greek. Leiden-Boston: Brill.

Benveniste, É. (1935). Origines de la formation des noms en indo-européen. Paris: Maisonneuve.

Blažek, V. (2015). Apollo the Archer (contribution presented at the International Colloquium on Ancient Greek Linguistics, Campus X, Rome, March 23-27, 2015).

Brixhe, C. (1976). Le dialecte grec de Pamphylie. Documents et grammaire. Paris: Maisonneuve.

Brown, E. L. (2004). In Search of Anatolian Apollo. In A. P. Chapin (Ed.), Charis. Essays in Honor of Sara A. Immerwahr (pp. 253-267). Princeton: Hesperia Supplement.

Burnet, J. (Ed.). (1903). Platonis Opera. Oxford: University Press.

$C A D=$ Gelb, I. J. (1968). The Assyrian Dictionary of the Oriental Institute of the University of Chicago (Vol. I). Chicago: Oriental Institute.

$C D A=$ Black, J., George, A., \& Postage, N. (Eds.). (2000). A Concise Dictionary of Akkadian. Wiesbaden: Harrassowitz.

Chantraine, P. (1968-1980). Dictionnaire étymologique de la langue grecque. Histoire des mots. Paris: Klincksieck.

Diakonoff, I. M., \& Starostin, S. A. (1986). Hurro-Urartian as an Eastern Caucasian Language. München: Kitzinger.

Evelyn-White, H. G. (Transl.). (1914). Hesiod: Theogony. In The Homeric Hymns and Homerica. Cambridge (MA): Harvard University Press - London: Heinemann.

Fowler, H. N. (Transl.). (1921). Plato in Twelve Volumes (Vol. 12). Cambridge (MA): Harvard University Press - London: Heinemann.

Frisk, H. (1973f.). Griechisches etymologisches Wörterbuch (Vol. I-III). Heidelberg: Winter.

García Trabazo, J. V. (2007). Ahhiyawafrage y cuestiones conexas. Podemos extraer más datos de las fuentes hititas? In J. J. Justel Vicente, B. E. Solans Gracia, J. P. Vita Barra, \& J. Á. Zamora López (Eds.), Las aguas primigenias: el Próximo Oriente Antiguo como fuente de civilización. Congreso Español de Antiguo Oriente Próximo, 4 2006, Zaragoza (pp. 43-68). Zaragoza: Instituto de Estudios Islámicos y del Oriente Próximo.

Gusmani, R. (1964). Lydisches Wörterbuch. Heidelberg: Winter.

Güterbock, H. G. (1986/1997). Troy in Hittite Texts? Wilusa, Ahhiyawa and Hittite History. In M. Mellink (Ed.), Troy and the Trojan War. A Symposium held at Bryn Mawr College. October 1984 (pp. 33-44). Bryn Mawr (Pen.): Bryn Mawr College. [Cited after the reedition in H. A. Hoffner, jr. (Ed.). (1997), Perspectives on Hittite Civilization: Selected Writings of Hans Gustav Güterbock (pp. 223-228). Chicago: The Oriental Institute of the University of Chicago].

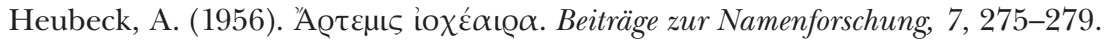

Heubeck, A. (1987). Noch einmal zum Namen des Apollon. Glotta, 65, 179-182.

Hintze, A. (1993). A Lexicon to the Cyprian Syllabic Inscriptions. Hamburg: Buske.

Hüsing, G. (1918). Kaspisch V: *lata = Eheweib? Orientalistische Literaturzeitung, 21, 264-272. 
$I C=$ Guarducci, M., \& Halbherr, F. (Eds.). (1935-1950). Inscriptiones Creticae. Roma: Libreria dello Stato (Istituto nazionale di archeologia e storia dell'arte, Italy).

ICS ${ }^{2}=$ Masson, O. (Ed.). (1983). Les inscriptions chypriotes syllabiques. Paris: de Boccard.

$I G=$ Böckh, A., Kirchhoff, A., \& Wilamowitz-Moellendorff, U. von et al. (Eds.). (1873f.). Inscriptiones Graecae. Berlin: Preussische Akademie der Wissenschaften / Brandenburgische Akademie der Wissenschaften.

Jones, W. H. S., \& Ormerod, H. A. (Transl.). (1918). Pausanias: Description of Greece. Cambridge (MA): Harvard University Press - London: Heinemann.

Laroche, E. (1980). Glossaire de la langue hourrite. Paris: Klincksieck.

Lichtenberg, A. (2008). The Variety of Local Religious Life in the Near East: In the Hellenistic and Roman Periods (Ed. T. Kaizer; pp. 133-154). Leiden-Boston: Brill.

Liddell, H. G., \& Scott, R. (1996). A Greek-English Lexicon (Revised and augmented throughout by Sir Henry Stuart Jones). Oxford: Clarendon Press.

$L I V=$ Rix, H., Kümmel, M., Zehnder, T., Lipp, R., \& Schirmer, B. (2001). Lexikon der indogermanischen Verben (2. ed.). Wiesbaden: Reichert.

Mair, A. W. (Ed. \& Transl.). (1921). Callimachus: Works. London: Heinemann - New York: Putnam's Sons.

Meineke, A. (Ed.). (1877). Strabo: Geographica. Leipzig: Teubner.

Monro, D. B. et al. (Eds.). (1920). Homeri Opera in five volumes. Oxford: Oxford University Press.

Murray, A. T. (Transl.). (1919). Homer: The Odyssey. Cambridge (MA): Harvard University Press London: Heinemann.

Murray, A. T. (Transl.). (1924). Homer: The Iliad. Cambridge (MA): Harvard University Press London: Heinemann.

NCED = Nikolaev, S. L., \& Starostin, S. A. (1994). A North Caucasian Etymological Dictionary. Moscow: Asterisk Publishers.

Neumann, G. (2007). Glossar des Lykischen (überarbeitet und zum Druck gebracht von Johann Tischler). Wiesbaden: Harrassowitz.

Nozadze, N. (2007). Leksika xurritskogo jazyka. Tbilisi: Society of Assyriologists, Bibliologists \& Caucasiologists.

Obbink, D. (2014). Two new poems by Sappho. Zeitschrift für Papyrologie und Epigraphik, 189, 32-49.

Oettinger, N. (2015). Apollo: indogermanisch oder nicht-indogermanisch? Münchener Studien zur Sprachwissenschaft, 69(1), 123-143.

Peters, M. (1980). Untersuchungen zur Vertretung der indogermanischen Laryngale im Griechischen (Philosophisch-Historische Klasse, Sitzungsberichte, Bd. 377). Wien: Österreichische Akademie der Wissenschaften.

Peters, M. (2002). Aus der Vergangenheit von Heroen und Ehegöttinnen. In M. Fritz, \& S. Zeilfelder (Eds.), Novalis indogermanica. Festschrift für Günter Neumann zum 80. Geburtstag (pp. 357-380). Graz: Leykam.

Pisani, V. (1947). Crestomazia indeuropea (2. ed.). Torino: Rosenberg \& Sellier.

Pokorny, J. (1959). Indogermanisches etymologisches Wörterbuch. München-Bern: Francke.

Ruijgh, C. J. (1967). Etudes sur la grammaire et le vocabulaire du grec mycénien. Amsterdam: Hakkert. Schwyzer, E. (1939). Griechische Grammatik, I. Band (Lautlehre. Wortbildung. Flexion). München: Beck. 
Smyth, H. W. (Transl.). (1926). Aeschylus: Agamemnon. Cambridge (MA): Harvard University Press - London: Heinemann.

Sommer, F. (1937). Ahhijijavā und kein Ende? Indogermanische Forschungen, 55, 169-297.

Spiro, F. (Ed.). (1903). Pausaniae Graeciae Descriptio. Leipzig: Teubner.

Stallbaum, G. (Ed.) (1825-1826). Eustathii, archiepiscopi thessalonicensis Commentarii ad Homeri Iliadem. Ad fidem exempli romani editi. Leipzig: Weigel. [Retrieved 18. 10. 2016 from https:// catalog.hathitrust.org/Record/008673527; http://khazarzar.skeptik.net/pgm/PG_Migne/Eustathius\%20Thessalonicensis_PG\%20135,136/Commentarii\%20ad\%20Homeri\%20Iliadem\%20 ii.pdf].

Taylor, T. (Ed.). (1792). Thy Hymns of Orpheus. London: T. Payne.

Usener, H. (1896). Götternamen. Versuch einer Lehre von der religiösen Begriffsbildung. Bonn: Cohen.

Ventris, M., \& Chadwick, J. (1973). Documents in Mycenaean Greek (2. ed.). Cambridge: University Press.

Wegner, I. (2007). Hurritisch. Eine Einführung (2. ed.). Wiesbaden: Harrassowitz.

Wernicke, K. (1895a). Apollon. In Paulys Realenzyclopädie der classischen Altertumswissenschaft (Bd. II.1; cc. 1-111). Stuttgart: Metzler. [Retrieved 18. 10. 2016 from http://de.wikisource.org/wiki/ RE:Apollon].

Wernicke, K. (1895b). Artemis. In Paulys Realencyclopädie der classischen Altertumswissenschaft (Bd. II.1; cc. 1336-1440). Stuttgart: Metzler. [Retrieved 18. 10. 2016 from https://de.wikisource.org/ wiki/RE:Artemis_2].

Wilamowitz-Moellendorff, U. von (Ed.). (1897). Callimachi hymni et epigrammata. Berlin: Weidmann. [Retrieved 18. 10. 2016 from http://data.perseus.org/texts/urn:cts:greekLit:tlg0533. tlg017.perseus-grc2].

Wilhelm, G. (2004). Hurrian. In R. D. Woodrow (Ed.), The Cambridge Encyclopedia of the World's Ancient Languages (pp. 95-118). Cambridge: University Press.

Willi, A. (2010). Hera, Eros, Iuno Sororia. Indogermanische Forschungen, 115, 234-267.

Windekens, A. J. van (1986). Dictionnaire étymologique complementaire de la langue grecque. Leuven: Peeters.

Acknowledgement:

The present contribution was prepared thanks to the grant of the The Czech Science Foundation (GAČR), GA15-12215S. The deepest thanks belong to Professor Heiner Eichner for his valuable comments and additions, to an anonymous referee for his important corrections and recommendations, and to John Bengtson for his revision of English.

Prof. RNDr. Václav Blažek, CSc. / blazek@phil.muni.cz

Department of Linguistics \& Baltic Studies

Masaryk University, Faculty of Arts

Arna Nováka 1, 60200 Brno, Czech Republic 